\title{
The Applicability of the River Continuum Concept to the Upper Reaches of a Neotropical Lower Montane Stream
}

\author{
Nicholas Skaff \\ Department of Biology \\ Tufts University \\ Medford, Massachusetts 02155 USA
}

\begin{abstract}
The applicability of the River Continuum Concept (RCC) to the upper reaches of Quebrada Máquina, a lower montane stream in Monteverde, Costa Rica, was examined. Macroinvertebrate samples were taken from ten points along the stream from first through fourth order segments. The families of the collected individuals were then categorized based on functional feeding group. The similarity between the families found at each collection point was calculated, along with correlations between the functional groups and various stream characteristics. In most cases, RCC predictions did not apply to Quebrada Máquina. The first (first order) and last (fourth order) sample points were $92 \%$ similar despite RCC predictions of substantial divergence in relative functional group abundance. This digression from the RCC predictions may be caused by the relatively few differences in stream characteristics between first and fourth order sections. Specifically, the observed similarities and correlations may have been determined by local scale heterogeneity of the stream characteristics.
\end{abstract}

\section{INTRODUCTION}

Dynamic abiotic and biotic interactions in pristine river ecosystems are extremely consistent due to the predictable biological responses to the physical components [1]. The River Continuum Concept (RCC) endeavors to systematically illustrate these patterns on a comprehensive scale. The basis of the RCC rests on the view that throughout the longitudinal river gradient, biological communities dynamically equilibrate with abiotic factors. In other words, the biological organization is dependent on the specific local allocation of kinetic energy through the physical system. For example, headwater community structure is largely shaped by riparian vegetation, which adds organic detritus to the channel and shades the river bottom, limiting autotrophic production. The specific energy distribution (including the influence of riparian vegetation) is greatly influenced by river size, which makes size categorization very important to the RCC [1]. The smallest consistently flowing stream is referred to as first order. Its mergence with another first order stream forms a second order and the coalescence of two second order streams produces a third order and so on [2]. The RCC generally accounts for river orders ranging from one to twelve [3].

Aquatic macroinvertebrates are often utilized in studying the biological responses of the system because they clearly reflect changes in food resource availability in relation to stream size [1]. Different abundances of specific functional feeding groups can be found along the longitudinal gradient. In general, many downstream organisms exploit upstream inefficiency in energy capture. Shredding (microbes gleaned from course organic matter like leaves) and collecting (microbes collected from direct water transport or fine sediment/organic matter) characterize first and second order stream macroinvertebrate species, while collecting and grazing (algae removed from substrate) are most commonly seen in mid-size fourth or fifth order rivers [1]. Near the mouth, collectors 


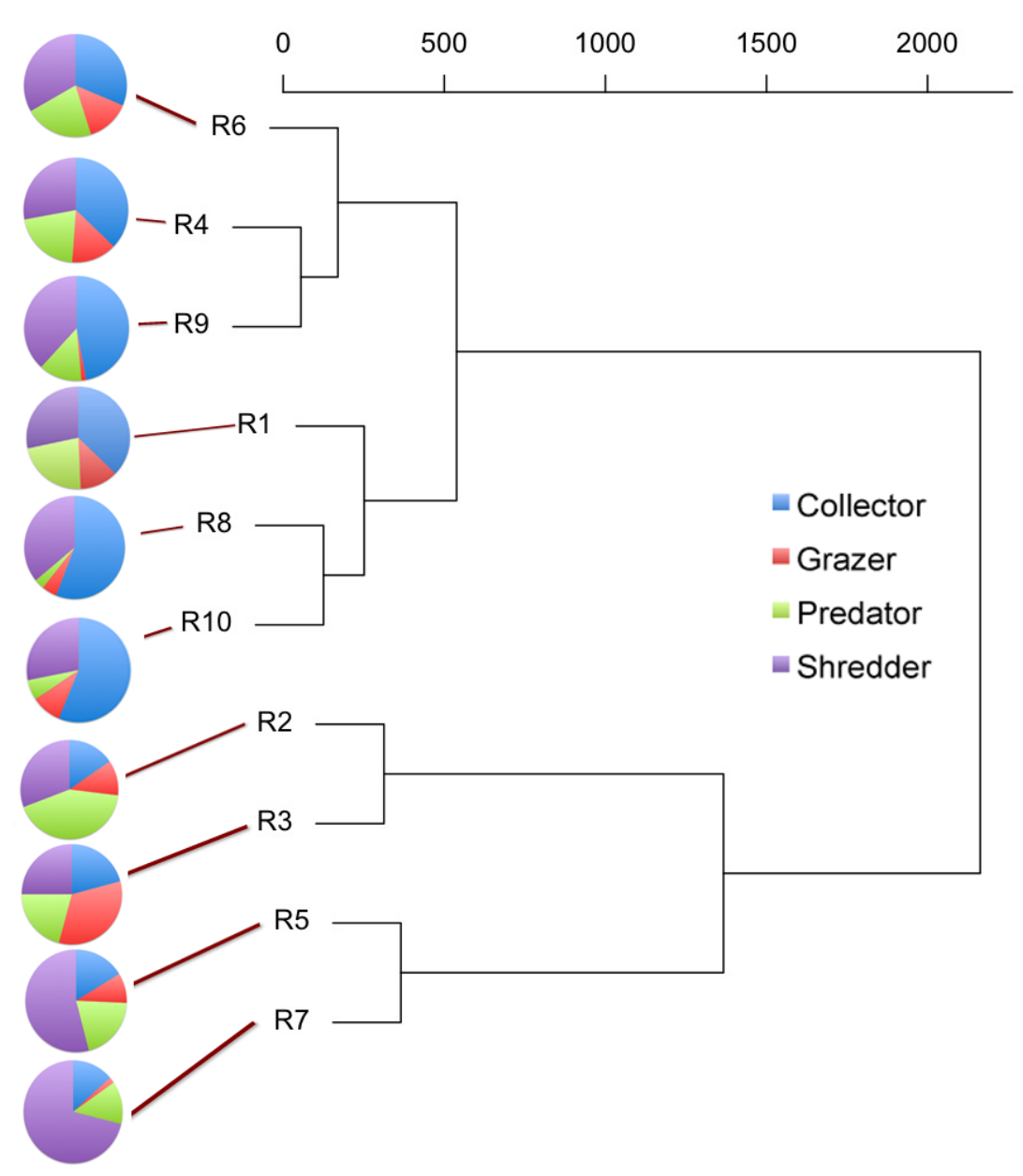

Figure 1. Site Similarity Clusters of Sampled Macroinvertebrates. Sample sites in Quebrada Máquina, Monteverde, Costa Rica, are grouped based on the similarity of the macroinvertebrate families present. Groups closer to the left axis are the most similar. The pie charts represent the relative abundance of each macroinvertebrate functional group at each site (for numerical data, see Appendix. B).

dominate, while predator abundance stays consistent throughout the system [1, 4].

Despite its temperate origins, the RCC has been applied successfully in the tropics [5]. However, there may be some circumstances in which trends in macroinvertebrate functional group structure differ from those expected by the continuum theory. Macroinvertebrates may persist in environments that the RCC would predict to be unsuitable by capitalizing on extreme local heterogeneity in the stream characteristics [6]. Nevertheless, I hypothesized that, overall, general trends in stream structure would dominate and macroinvertebrate species composition would follow RCC predictions in Quebrada Máquina, a neotropical lower montane stream.

\section{METHODS}

\section{a. Study Location}

Macroinvertebrates were collected at ten points along Quebrada Máquina in Monteverde, Costa Rica between $1690 \mathrm{~m}$ (Sample Site 1) and $1440 \mathrm{~m}$ (Sample Site 10). The stream originates high in the Tilarán Mountain Range (maximum elevation $1850 \mathrm{~m}$ ), which represents the continental divide [7]. Beginning above the 


\begin{tabular}{|c|c|c|c|c|c|c|c|c|c|c|}
\hline $\begin{array}{c}\text { Site } \\
\text { Number }\end{array}$ & 1 & 2 & 3 & 4 & 5 & 6 & 7 & 8 & 9 & 10 \\
\hline 1 & $100 \%$ & & & & & & & & & \\
\hline 2 & $47 \%$ & $100 \%$ & & & & & & & & \\
\hline 3 & $50 \%$ & $53 \%$ & $100 \%$ & & & & & & & \\
\hline 4 & $91 \%$ & $54 \%$ & $51 \%$ & $100 \%$ & & & & & & \\
\hline 5 & $61 \%$ & $52 \%$ & $42 \%$ & $82 \%$ & $100 \%$ & & & & & \\
\hline 6 & $85 \%$ & $40 \%$ & $44 \%$ & $87 \%$ & $72 \%$ & $100 \%$ & & & & \\
\hline 7 & $55 \%$ & $13 \%$ & $24 \%$ & $66 \%$ & $69 \%$ & $67 \%$ & $100 \%$ & & & \\
\hline 8 & $88 \%$ & $26 \%$ & $40 \%$ & $85 \%$ & $54 \%$ & $86 \%$ & $71 \%$ & $100 \%$ & & \\
\hline 9 & $84 \%$ & $28 \%$ & $41 \%$ & $91 \%$ & $78 \%$ & $88 \%$ & $83 \%$ & $93 \%$ & $100 \%$ & \\
\hline 10 & $92 \%$ & $28 \%$ & $41 \%$ & $86 \%$ & $51 \%$ & $82 \%$ & $63 \%$ & $96 \%$ & $88 \%$ & $100 \%$ \\
\hline
\end{tabular}

Table 1. Percent Similarity (Morisita's Index of Similarity) of Macroinvertebrate Families Between Sample Sites. Sites one through ten represent adjacent sample sites in Quebrada Máquina, Monteverde, Costa Rica, with site one in the first order stream section (highest elevation) and site ten in the lowest fourth order section.

Estación Biológica in lower montane forest, the stream extends into the adjacent valley. On two separate occasions, five samples were taken every $30 \mathrm{~m}$ increase in elevation above the Estación and every $15 \mathrm{~m}$ drop in elevation after the waterfall below the Estación. The elevation adjustment was made to accommodate a decrease in stream slope in the lower half. In each of the two collection rounds, one sample was taken in both first and second order sections of the stream, three samples were taken in third order sections, and five samples were collected in fourth order sections. The sample areas were rectangles five meters long (parallel with stream flow) and the width of the stream (perpendicular to stream flow). This site size was selected to maximize macroinvertebrate capture and limit local site variation like elevation and substrate composition.

\section{b. Sampling}

Sampling occurred between 9 November and 20 November 2009. Prior to macroinvertebrate collection, local stream characteristics were noted. The approximate distance from the nearest upstream waterfall, the percent substrate composition of rock, sand and vegetation detritus, stream width, depth, grade and elevation were all recorded. Macroinvertebrates were collected for 45 minutes at each sample point using a benthic macroinvertebrate collection sieve. The substrate was disturbed for approximately 45 seconds using a hand rake, while the sieve was held downstream. Dislodged invertebrates in the sieve were then preserved in vials containing $80 \%$ ethanol. This process was repeated many times over the sample period in the entire range of local stream bottom compositions (vegetation detritus, rocks, sand).

c. Identification

Macroinvertebrate samples were identified in the lab using a dissecting microscope. The identifications were made with Lehmkuhl [8] as a reference. Individuals were identified to family with the exception of leaches, Stylommatophora, and Isopoda (excluding Armadillidiidae). In order to assess the applicability of the River Continuum Concept, individual macroinvertebrate families from specific sample sites were grouped into their respective function feeding groups using [9].

\section{d. Data Analysis}

The relative abundance of each functional feeding group was calculated by site. Morisita's Index of Similarity was used to measure the percent similarity between macroinvertebrate samples at each site using families as taxa. With JMP 5.0.1a, the similarity percentages were combined to 


\begin{tabular}{|c|c|c|c|c|}
\hline Variable A & Variable B & Rho & N-Value & P-Value \\
\hline \multirow[t]{4}{*}{ Site } & Collector & 0.41 & 10 & 0.24 \\
\hline & Grazer & -0.56 & 10 & 0.09 \\
\hline & Predator & -0.61 & 10 & 0.06 \\
\hline & Shredder & 0.40 & 10 & 0.35 \\
\hline
\end{tabular}

Table 2. Pairwise Correlations Between Sample Site and Macroinvertebrate Function Feeding Group in Quebrada Máquina, Monteverde, Costa Rica.

\begin{tabular}{l|c|c|c|c}
\hline \multicolumn{1}{c}{ Variable A } & Variable B & Rho & N-Value & P-Value \\
\hline \% Sand & Collector & -0.03 & 10 & 0.92 \\
& Grazer & -0.71 & 10 & 0.02 \\
& Predator & -0.29 & 10 & 0.41 \\
& Shredder & 0.50 & 10 & 0.14 \\
Stream Width & Collector & 0.61 & 10 & 0.06 \\
& Grazer & -0.44 & 10 & 0.20 \\
& Predator & -0.42 & 10 & 0.23 \\
& Shredder & 0.64 & 10 & 0.05 \\
& & & & 0.8 \\
& Collector & 0.09 & 10 & 0.01 \\
& Grazer & -0.75 & 10 & 0.1 \\
& Predator & -0.54 & 10 & 0.37
\end{tabular}

Table 3. Pairwise Correlations Between Recorded Stream Characteristics and Macroinvertebrate Functional Feeding Groups in Quebrada Máquina, Monteverde, Costa Rica.

\begin{tabular}{|c|c|c|c|c|c|c|c|c|}
\hline \multirow[b]{2}{*}{ Site } & \multirow{2}{*}{$\begin{array}{c}\text { Distance } \\
\text { from } \\
\text { Waterfall }\end{array}$} & \multicolumn{3}{|c|}{ Substrate } & \multirow[b]{2}{*}{$\begin{array}{l}\text { Water } \\
\text { Depth }\end{array}$} & \multirow[b]{2}{*}{ Width } & \multirow[b]{2}{*}{$\begin{array}{c}\% \\
\text { Grade }\end{array}$} & \multirow[b]{2}{*}{ Elevation } \\
\hline & & $\begin{array}{c}\% \\
\text { Rock }\end{array}$ & $\begin{array}{c}\text { \% Veg } \\
\text { Detritus }\end{array}$ & $\begin{array}{c}\% \\
\text { Sand }\end{array}$ & & & & \\
\hline 1 & 50 & 60 & 40 & 0 & 2 & 1 & 10 & 1690 \\
\hline 2 & 3 & 40 & 60 & 0 & 4 & 0.75 & 35 & 1660 \\
\hline 3 & 25 & 90 & 10 & 0 & 8 & 1.5 & 10 & 1630 \\
\hline 4 & 35 & 70 & 30 & 0 & 5 & 2 & 20 & 1600 \\
\hline 5 & 50 & 80 & 20 & 0 & 8 & 2 & 10 & 1570 \\
\hline 6 & 10 & 80 & 20 & 0 & 11 & 2 & 10 & 1500 \\
\hline 7 & 35 & 35 & 5 & 60 & 22 & 3 & 5 & 1485 \\
\hline 8 & 50 & 85 & 5 & 10 & 11 & 3.5 & 15 & 1470 \\
\hline 9 & 50 & 75 & 5 & 20 & 21 & 3.5 & 10 & 1455 \\
\hline 10 & 50 & 80 & 10 & 10 & 20 & 2 & 20 & 1440 \\
\hline
\end{tabular}

Table 4. Recorded Stream Characteristics at Sample Sites in Quebrada Máquina, Monteverde, Costa Rica. Distance from waterfall represents the horizontal distance from the sample site to the nearest upstream waterfall. The percent rock, vegetation detritus, and sand represent the total substrate composition at each sample site. The percent grade is the slope of the streambed. 


\begin{tabular}{|c|c|c|c|c|}
\hline Variable A & Variable B & Rho & N-Value & P-Value \\
\hline \multirow[t]{7}{*}{ Elevation } & Distance WC & -0.34 & 10 & 0.03 \\
\hline & \% Rock & -0.25 & 10 & 0.48 \\
\hline & \% Veg. Det. & 0.77 & 10 & 0.008 \\
\hline & $\%$ Sand & -0.49 & 10 & 0.14 \\
\hline & Water Depth & -0.87 & 10 & 0.0009 \\
\hline & Width & -0.82 & 10 & 0.003 \\
\hline & $\%$ Grade & 0.29 & 10 & 0.41 \\
\hline
\end{tabular}

Table 5. Pairwise Correlations Between Sample Site Elevation and the Recorded Stream Characteristics in Quebrada Máquina, Monteverde, Costa Rica.

form a hierarchical cluster diagram, grouping the sites with the most similar macroinvertebrate assemblages [10]. Pairwise correlations were calculated between functional feeding group and site location, stream characteristics and stream order. Finally, elevation and the local stream characteristics were tested for correlation.

\section{RESULTS}

Overall, 572 individual macroinvertebrates were collected, representing 12 orders and 24 families (Appendix A). The most similar sites based on macroinvertebrate family and functional feeding group seem to be unrelated spatially (Figure 1). For example, Sites 1 and 10 are approximately $92 \%$ similar in macroinvertebrate family abundance and presence, yet they represent complete opposite ends of the longitudinal spectrum (Table 1). When the families are placed in function groups, the same site similarities are apparent (Figure 1, for specific abundances see Appendix B). Further confirmation can be seen in the lack of significant correlation between relative functional group abundance and site location (Table 2).

However, some of the recorded stream characteristics (Table 4) show significant correlations (Table 3) with specific functional groups. There is a negative relationship between the proportion of grazers and the sandiness of the substrate. A higher percentage of sand on the stream bottom indicates a lower proportion of grazers. Nevertheless, there is no significant correlation between the substrate sandiness and elevation (Table 5). Also, grazer abundances are negatively correlated with water depth and shredder abundances are positively correlated with stream width. All other stream characteristic and functional group relationships are not statistically significant. Despite the relationships between stream characteristics and functional group abundance, there are no significant relationships between functional group and site location (Table 2). The strongest is a marginally significant negative relationship between site and predator abundance.

Conversely, quite a few significant correlations can be found between elevation and other recorded stream characteristics (Table 5). Elevation is positively correlated with vegetation detritus and negatively correlated with both water depth and stream width. This means that higher order streams (lower elevations) tend to have substrates with less vegetation detritus and that lower order streams are both wider and deeper than those found at higher elevations.

\section{DISCUSSION}

It appears that the stage has been properly set for the River Continuum Concept's macroinvertebrate predictions in that the appropriate abiotic and biotic stream characteristics are correlated. It is predicted that down an elevational or stream order gradient there will be stream widening and deepening, which has been found. Also supported by the results, the concept predicts that with stream widening there will be less vegetation detritus in the substrate [1]. However, the trends found in relative functional group abundance do not 
correspond with tendencies predicted by the RCC. Following a review of the various discrepancies, an explanation will be provided.

The strong negative correlation found between predator abundance and stream order is in direct opposition to what is expected by the RCC. The RCC assumes that the other three functional groups depend on one general type of food source (e.g. Grazers depend on algae etc.). Fluctuations in this resource cause the proportions of these functional groups to change. However, predator populations only depend on the relative abundances of the other functional groups. Therefore, no matter how the grazers, shredders and collectors respond to resource availability, the relative predator population should stay the same [1]. For this reason, the observed change in the proportion of predators is quite surprising. The actual proportions of grazers also run contrary to the expected. The RCC assumes that the highest proportion of grazers will be present in midorder streams due to the elevated levels of algal growth associated with a wider stream and a relatively shallow channel [1]. The data from this study illustrates that this is not the case. The lack of correlation between site number and shredder abundance is also unexpected. Shredders are typically higher in abundance in the headwaters due to more leaf detritus off of which they feed.

Finally, according to the RCC, no large correlation should be found between site and collector abundance in low to midorder streams. The correlations did support this prediction (there was no correlation), however, this was not due to consistency in the observed proportion of collectors, but rather the lack of consistency. High proportions were found intermixed with low proportions at various points throughout the stream order gradient (Figure 1). According to the RCC, relative collector abundances should stay around $50 \%$ in the sampled portions of Quebrada Máquina [1].

One possible explanation for the disparity in observed and expected feeding group proportions may be the relatively small ranges of physical stream characteristics found between the stream orders. For example, the first order and fourth order portions of Quebrada Máquina only differed in width by $2.5 \mathrm{~m}$. However, just third and fourth order sections of the Dolores River in Colorado ranged from 7.3 $\mathrm{m}$ to $16.8 \mathrm{~m}$ wide over an elevation range of $500 \mathrm{~m}$ [11]. The relatively small width change in Quebrada Máquina may limit the disparity between orders, making any differences in functional group presence much less apparent. The use of order to characterize a stream is sometimes deemed to be a misrepresentation of the true size. Some consider drainage area and discharge to be better indicators [12]. If the drainage area and discharge rates of Quebrada Máquina equate best with the typical first order stream, then it may be best to expect first order macroinvertebrate abundances. The RCC's failure to explain the observed macroinvertebrate presence may be more a failure of the stream order classification system than the RCC itself. Future research could investigate this relationship.

In a stream that shows little size change across orders, the specific results found may best be explained by the local heterogeneity of stream characteristics. The results from Quebrada Máquina seem to illustrate this idea. Of the correlations performed, the highest number of significant correlations was found in comparisons of local stream characteristics and functional group abundance. For example, the relative proportion of grazers was significantly correlated with the water depth and the sandiness of the substrate, but was not correlated with stream order. Randomly, some of the sample sites may have contained deeper water or a sandier substrate. A tree fall across the stream may have raised water depth and caused sediment build up. An event such as this is not influenced by stream order, but rather by chance. Incidences like this one may frequently be masked by the more general trends in water depth and substrate composition such as those predicted by the RCC. However, the narrow stream characteristic ranges in Quebrada Máquina possibly accentuated chance heterogeneity and precluded correct RCC predictions. This is supported by DeAngelis and Waterhouse's [13] conclusion that the idea of stream equilibrium (essentially the RCC) depends greatly on the scale of the study. On a large scale, the overall effect may be greater than the individual components, 
enabling the function of systems like the RCC [12].

\section{ACKNOWLEDGEMENTS}

I would like to thank Pablo Allen for his courage and fortitude in helping me plan this project and for the many hours he spent helping me identify the macroinvertebrate families. Also, I would like to express appreciation for Anna Stuart's tireless help in teaching me stream sampling and water testing techniques. I would like to give a small but special thanks to Blaine Marchant for literally getting me on the right path. Finally, I want to thank CIEE: Costa Rica and the Estación Biologica for giving me the opportunity to gain valuable experience in field research in one of the world's most beautiful forests.

\section{LITERATURE CITED}

1. Vannote, Robin L, G. Wayne Minshall, Kenneth W. Cummins, James R. Sedell, and Cobert E. Cushing. "The River Continuum Concept" Can. J. Fish. Aquat. Sci. 37 (1980) 130-137.

2. Allan, J.D., and M.M. Castillo. Stream Ecology: Structure and Function of Running Water. $2^{\text {nd }}$ Ed. (Springer, Netherlands, 2007).

3. Thorp, J.H. and A.P. Covich, Eds. Ecology and Classification of North American Freshwater Invertebrates (Academic Press, New York, 1991)

4. Hawkins, C.P. and J.R. Sedell. "Longitudinal and seasonal changes in functional organization of macroinvertebrate" Ecology 64(2) (1981) 387-397.

5. Greathouse, E.A., and C.M. Pringle. "Does the river continuum concept apply on a tropical island? Longitudinal variation in a Puerto Rican stream" Can. J. Fish Aquat. Sci. 63 (2006) 134-152.

6. Lancaster, J. and L.R. Belya. "Nested hierarchies and scale-dependence of mechanisms of flow refugium use" Journal of the North American Benthological Society 16(1) (1997) 221238.

7. Jankowski, J.E. and K.N. Rabenold. "Endemism and local rarity in birds of neotropical montane rainforest"
Biological Conservation 138 (2007) 453463.

8. Lehmkuhl, D.M. How to Know the Aquatic Insects (Pictured Key Nature Series, Dubuque, lowa, 1979)

9. Merritt, R.W., and K.W. Cummins. An Introduction to the Aquatic Insects of North America (Kendall/Hunt, Dubuque, lowa, 1996)

10. Krebs, C.B. Ecological Methodology (Addison Wesley Longman, Menlo Park, ca, 1999)

11. Canton, S.P. and J.W. Chadwick. "Season and longitudinal changes in macroinvertebrate functional groups in the Dolores River, Colorado" North American Benthological Society. 2(1) (1983) 41-47.

12. Allen, T.F.H, and T.W. Hoekstra. Toward a Unified Ecology (Columbia University Press, New York, 1992)

13. DeAngelis, D.L., and J.C. Waterhouse. "Equilibrium and nonequilibrium concepts in ecological models" Ecological Monographs. 57 (1987) 1-21.

NOTE: Appendices follow on the next two pages.

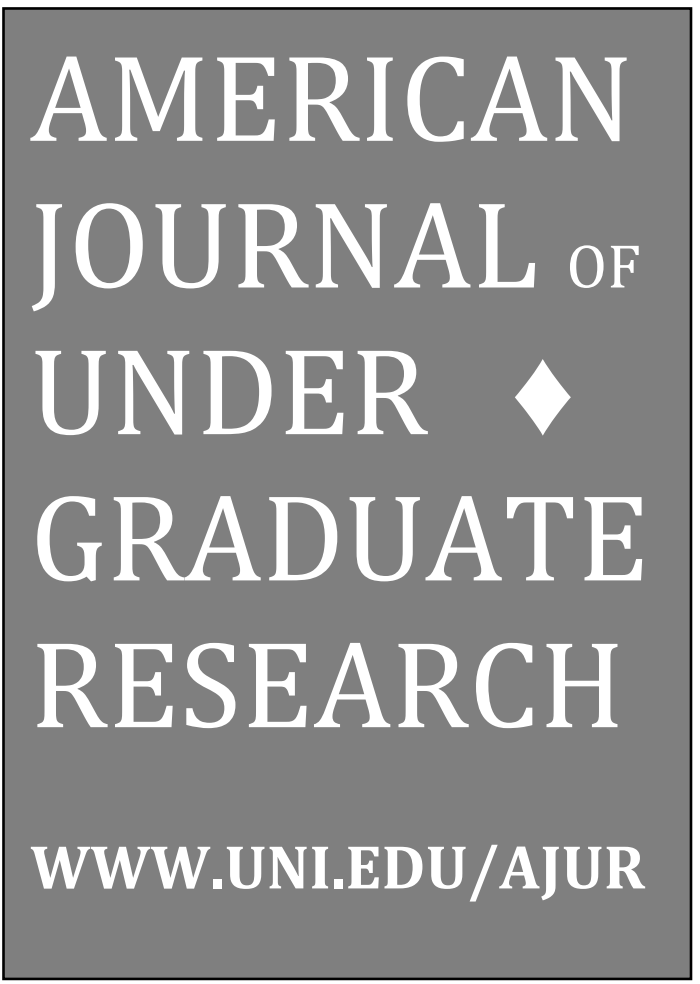




\section{APPENDIX A}

Complete Macroinvertebrate Sample Data for Quebrada Máquina, Monteverde, Costa Rica. Total abundance for families found at each site are listed in the far-right column.

\begin{tabular}{|c|c|c|c|}
\hline Sample & Order & Family & Indiv. \\
\hline \multicolumn{4}{|l|}{ Site } \\
\hline 1 & Ephemeroptera & Baetidae & 2 \\
\hline 1 & Muluska & Gastropoda & 1 \\
\hline 1 & Odonata & Gomphidae & 8 \\
\hline 1 & Trichoptera & Hydropsychidae & 25 \\
\hline 1 & Plecoptera & Perlidae & 4 \\
\hline 1 & Odonata & Pelytheridae & 1 \\
\hline 1 & Coleoptera & Ptilodactylidae & 14 \\
\hline 1 & Coleoptera & Staphylinidae & 1 \\
\hline 1 & Diptera & Tipulidae & 2 \\
\hline 1 & Isopoda & Unknown & 3 \\
\hline 1 & Stylommatophora & Unknown & 5 \\
\hline 1 & Leach & Unknown & 1 \\
\hline 2 & Ephemeropterd & Baetidae & 2 \\
\hline 2 & Blattaria & Blaberidae & 2 \\
\hline 2 & Coleoptera & Dytiscidae & 2 \\
\hline 2 & Coleoptera & Elmidae & 1 \\
\hline 2 & Odonata & Gomphidae & 1 \\
\hline 2 & Trichoptera & Hydropsychidae & 2 \\
\hline 2 & Ephemeroptera & Leptophlebiidae & 2 \\
\hline 2 & Plecoptera & Perlidae & 6 \\
\hline 2 & Odonata & Pelytheridae & 1 \\
\hline 2 & Coleoptera & Ptilodactylidae & 1 \\
\hline 2 & Coleoptera & Staphylinidae & 1 \\
\hline 2 & Diptera & Tipulidae & 2 \\
\hline 2 & Isopoda & Unknown & 3 \\
\hline 3 & Ephemeroptera & Baetidae & 7 \\
\hline 3 & Coleoptera & Dytiscidae & 1 \\
\hline 3 & Coleoptera & Elmidae & 1 \\
\hline 3 & Trichoptera & Hydrobiosidae & 2 \\
\hline 3 & Trichoptera & Hydropsychidae & 3 \\
\hline 3 & Ephemeropterd & Leptophlebiidae & 2 \\
\hline 3 & Odonata & Pelytheridae & 1 \\
\hline 3 & Coleoptera & Ptilodactylidae & 2 \\
\hline 3 & Diptera & Tipulidae & 2 \\
\hline 3 & Isopoda & Unknown & 2 \\
\hline 3 & Leach & Unknown & 1 \\
\hline 4 & Ephemeroptera & Baetidae & 1 \\
\hline 4 & Coleoptera & Elmidae & 1 \\
\hline 4 & Ephemeroptera & Euthyplocidae & 1 \\
\hline 4 & Trichoptera & Hydropsychidae & 12 \\
\hline 4 & Ephemeroptera & Leptohyphidae & 2 \\
\hline 4 & Ephemeroptera & Leptophlebiidae & 1 \\
\hline 4 & Plecoptera & Perlidae & 5 \\
\hline 4 & Coleoptera & Ptilodactylidae & 12 \\
\hline 4 & Leach & Unknown & 4 \\
\hline 4 & Stylommatophora & Unknown & 4 \\
\hline 5 & Ephemeropterd & Baetidae & 1 \\
\hline 5 & Ephemeroptera & Euthyplocidae & 1 \\
\hline 5 & Odonata & Gomphidae & 1 \\
\hline 5 & Trichoptera & Hydropsychidae & 3 \\
\hline 5 & Ephemeroptera & Leptohyphidae & 3 \\
\hline 5 & Ephemeroptera & Leptophlebiidae & 1 \\
\hline 5 & Odonata & Meqapodagrionidae & 1 \\
\hline 5 & Hemiptera & Naucoridae & 2 \\
\hline 5 & Plecoptera & Perlidae & 10 \\
\hline
\end{tabular}

\begin{tabular}{|c|c|c|c|}
\hline Sample & Order & Family & Indiv. \\
\hline \multicolumn{4}{|l|}{ Site } \\
\hline 5 & Odonata & Pelytheridae & 1 \\
\hline 5 & Coleoptera & Ptilodactylidae & 27 \\
\hline 5 & Diptera & Simuliidae & 4 \\
\hline 5 & Diptera & Tipulidae & 4 \\
\hline 5 & Isapoda & Unknown & 9 \\
\hline 5 & Leach & Unknown & 7 \\
\hline 5 & Stylommatophora & Unknown & 6 \\
\hline 6 & Odonata & Calopteryqidae & 3 \\
\hline 6 & Coleoptera & Dryopidae & 1 \\
\hline 6 & Coleoptera & Elmidae & 1 \\
\hline 6 & Odonata & Gomphidae & 1 \\
\hline 6 & Trichoptera & Hydropsychidae & 13 \\
\hline 6 & Hemiptera & Naucoridae & 7 \\
\hline 6 & Plecoptera & Perlidae & 2 \\
\hline 6 & Coleoptera & Ptilodactylidae & 14 \\
\hline 6 & Diptera & Simuliidae & 3 \\
\hline 6 & Diptera & Tipulidae & 3 \\
\hline 6 & Stylommatophora & Unknown & 5 \\
\hline 7 & Odonata & Aeshnidae & 1 \\
\hline 7 & Odonata & Calopteryqidae & 1 \\
\hline 7 & Odonata & Coenagrionidae & 1 \\
\hline 7 & Trichoptera & Hydropsychidae & 7 \\
\hline 7 & Hemiptera & Naucoridae & 3 \\
\hline 7 & Coleoptera & Ptilodactylidae & 37 \\
\hline 7 & Stylommatophora & Unknown & 1 \\
\hline 7 & Leach & Unknown & 1 \\
\hline 7 & Trichoptera & Unknown Morpho 1 & 1 \\
\hline 8 & Odonata & Aeshnidae & 1 \\
\hline 8 & Isopoda & Armadillid lidae & 1 \\
\hline 8 & Ephemeroptera & Baetidae & 1 \\
\hline 8 & Blattaria & Blaberidae & 1 \\
\hline 8 & Odonata & Calopteryqidae & 1 \\
\hline 8 & Coleoptera & Elmidae & 4 \\
\hline 8 & Trichoptera & Hydropsychidae & 54 \\
\hline 8 & Ephemeroptera & Leptohyphidae & 4 \\
\hline 8 & Ephemeroptera & Leptophlebiidae & 1 \\
\hline 8 & Hemiptera & Naucoridae & 1 \\
\hline 8 & Coleoptera & Ptilodactylidae & 43 \\
\hline 8 & Diptera & Simuliidae & 11 \\
\hline 8 & Leach & Unknown & 1 \\
\hline 8 & Stylommatophora & Unknown & 1 \\
\hline 9 & Odonate & Calopteryqidae & 1 \\
\hline 9 & Trichoptera & Hydropsychidae & 18 \\
\hline 9 & Ephemeroptera & Leptohyphidae & 3 \\
\hline 9 & Ephemeroptera & Leptohyphidae & 5 \\
\hline 9 & Ephemeroptera & Leptophlebiidae & 1 \\
\hline 9 & Coleoptera & Ptilodactylidae & 26 \\
\hline 9 & Diptera & Simuliidae & 5 \\
\hline 9 & Leach & Unknown & 7 \\
\hline 9 & Stylommatophora & Unknown & 1 \\
\hline 9 & Hemiptera & Velidae & 1 \\
\hline 10 & Odonata & Calopteryqidae & 1 \\
\hline 10 & Trichoptera & Hydropsychidae & 16 \\
\hline 10 & Ephemeroptera & Leptophlebiidae & 1 \\
\hline 10 & Odonata & Meqapodacrionidae & 1 \\
\hline 10 & Coleoptera & Ptilodactylidae & 9 \\
\hline 10 & Diptera & Simuliidae & 1 \\
\hline 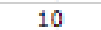 & Stylommatopho & Unknown & 3 \\
\hline
\end{tabular}




\section{APPENDIX B}

Relative Abundance of Macroinvertebrate Functional Groups in Site Samples Taken at Quebrada Máquina, Monteverde, Costa Rica.

\begin{tabular}{r|c|c|c|c}
\hline \multicolumn{1}{c}{ Site } & \multicolumn{1}{c}{ Collector } & \multicolumn{1}{c}{ Grazer } & \multicolumn{1}{c}{ Predator } & Shredder \\
\hline 1 & $37.3 \%$ & $11.9 \%$ & $22.4 \%$ & $28.4 \%$ \\
2 & $15.4 \%$ & $11.5 \%$ & $42.3 \%$ & $30.8 \%$ \\
3 & $20.8 \%$ & $33.3 \%$ & $20.8 \%$ & $25.0 \%$ \\
4 & $37.2 \%$ & $14.0 \%$ & $20.9 \%$ & $27.9 \%$ \\
5 & $16.2 \%$ & $9.5 \%$ & $20.3 \%$ & $54.1 \%$ \\
6 & $31.4 \%$ & $13.7 \%$ & $21.6 \%$ & $33.3 \%$ \\
7 & $13.5 \%$ & $1.9 \%$ & $13.5 \%$ & $71.2 \%$ \\
8 & $56.0 \%$ & $4.8 \%$ & $3.2 \%$ & $36.0 \%$ \\
9 & $47.1 \%$ & $1.5 \%$ & $13.2 \%$ & $38.2 \%$ \\
10 & $56.3 \%$ & $9.4 \%$ & $6.3 \%$ & $28.1 \%$
\end{tabular}
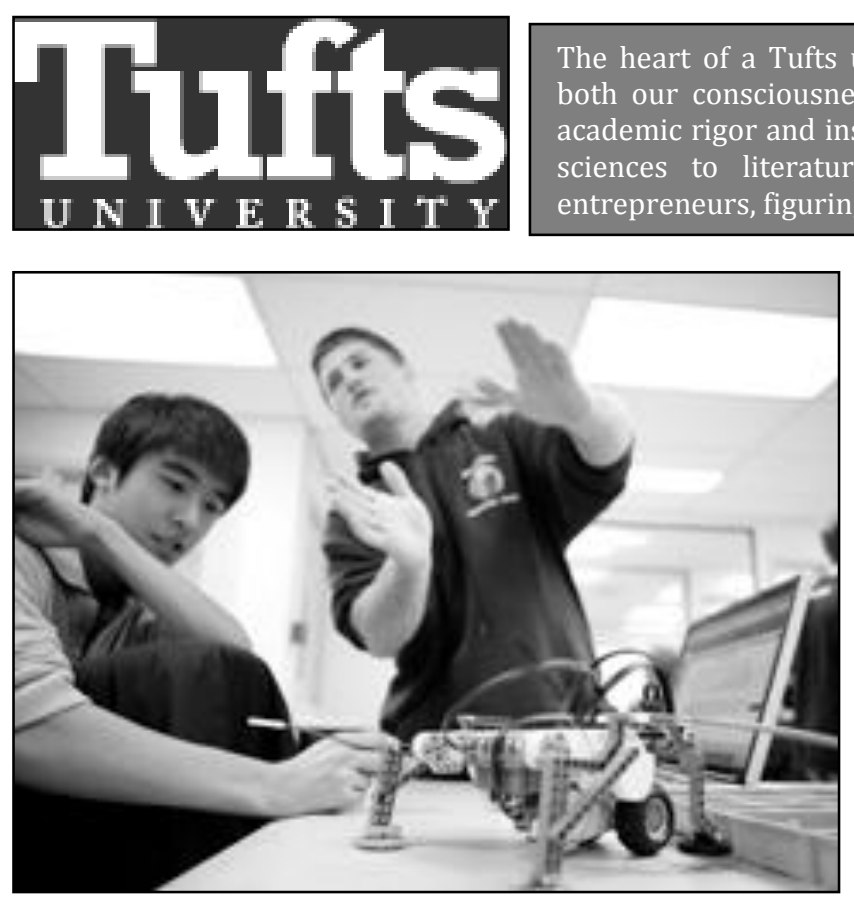

www.tufts.edu

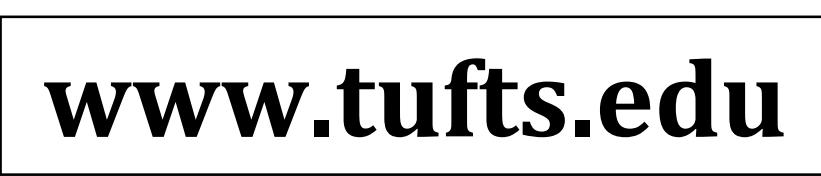

The heart of a Tufts undergraduate education is the exploration of both our consciousness and our society. Tufts fosters a culture of academic rigor and inspired scholarship in a range of fields, from life sciences to literature. Our students are problem solvers and entrepreneurs, figuring out solutions for the challenges ahead.
At Tufts, you can major in more than 70 undergraduate degree programs and have your pick from thousands of undergraduate courses. There are approximately 5,000 undergraduate students at Tufts, about 80 percent in the School of Arts and Sciences and 20 percent in the School of Engineering.

The majority of courses are taught by full-time professors, most of whom hold a Ph.D and many of whom are practicing professionals in their fields. The university strives to foster personal relationships between students and faculty, encouraging individual attention in both the classroom and research settings. 


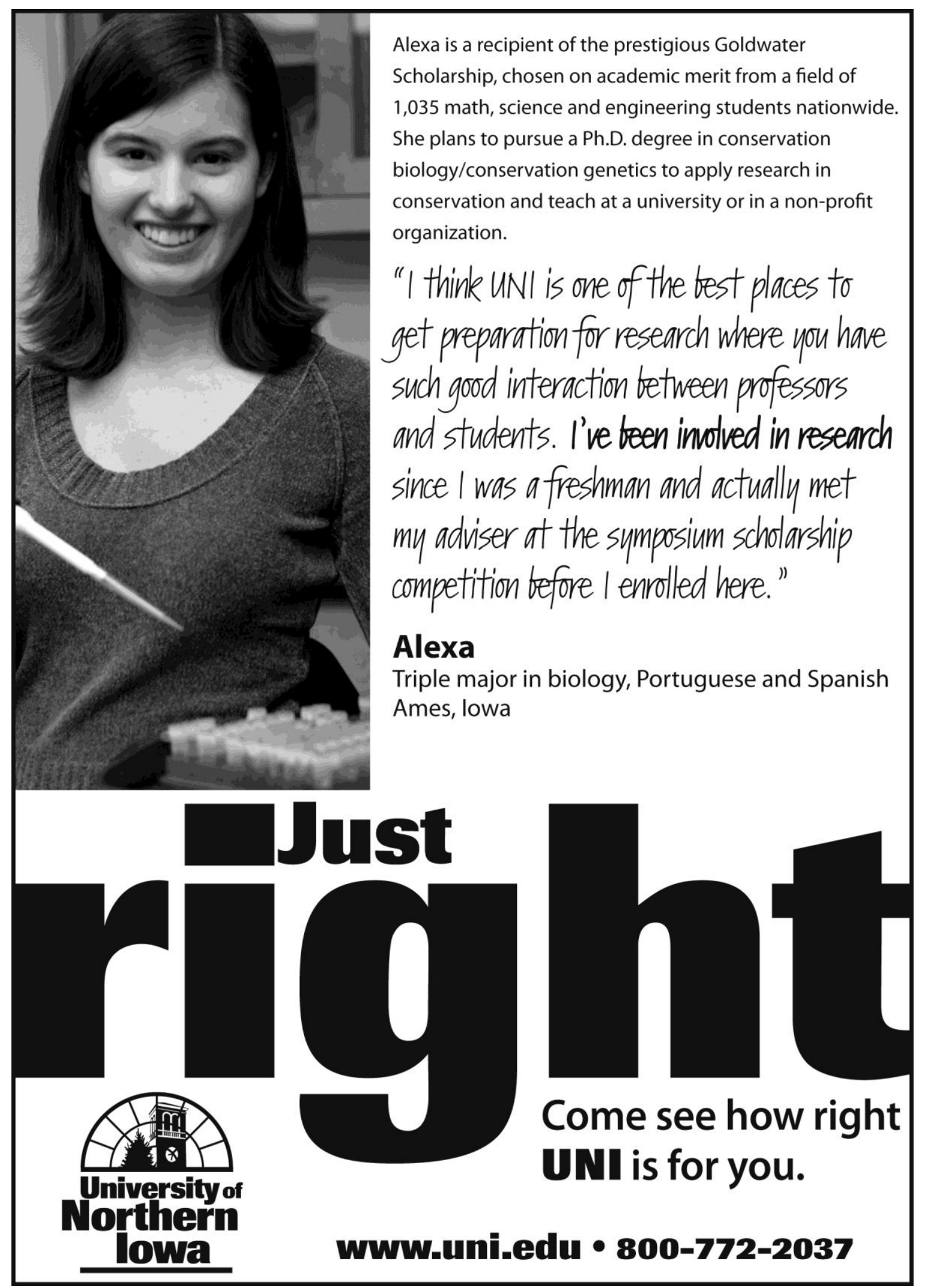

